\title{
Pyritic metals sequestration on mine dumps treated with oyster mushroom (Pleurotus ostreatus, Jacq.et Fr.)
}

Johnson Masaka ${ }^{*}$, Marshall Mutambu$^{1}$, Rangarirayi Mhindu and Kudakwashe Muringaniza²

\begin{abstract}
Background: Mining activities can lead to the generation of large quantities of heavy metal laden wastes which are released into the environment in an uncontrolled manner, causing widespread contamination of the ecosystem. Bioremediation is an innovative and promising technology available for removal and recovery of heavy metals from polluted environments.
\end{abstract}

Methods: Field experiments based on a Latin Square Design were employed in this study in order to determine the effectiveness of oyster mushroom (P. ostreatus) as a bioremediation agent for the sequestration of pyritic heavy metals from mine dumps.

Results: Compared with the background values of heavy metals in virgin forest soil, concentrations of $\mathrm{Mn}^{2+} ; \mathrm{Cr}^{2+}$; $\mathrm{Pb}^{2+} ; \mathrm{Fe}^{3+}$; and $\mathrm{Cd}^{2+}$ were substantially enriched in the study sites. The propagation of oyster mushroom in wheat straw substrate and heavy metal-polluted pyritic mine waste, reduced considerably the concentrations of mobile heavy metals in the waste by $1.2 \mathrm{mg} \mathrm{kg}^{-1}(98 \%) ; 2.0 \mathrm{mg} \mathrm{kg}^{-1}$ (79\%); $13.1 \mathrm{mg} \mathrm{kg}^{-1}(93 \%) ; 7.7 \mathrm{mg} \mathrm{kg}^{-1}$ (78\%); and $6.5 \mathrm{mg} \mathrm{kg}^{-1}$ (88\%) for $\mathrm{Mn}^{2+} ; \mathrm{Cr}^{2+} ; \mathrm{Pb}^{2+} ; \mathrm{Fe}^{3+}$; and $\mathrm{Cd}^{2+}$, respectively. Results have shown that the greatest threat to the ecology in the mine dump sites is currently posed by $\mathrm{Cd}^{2+}$; $\mathrm{Fe}^{3+}$; and $\mathrm{Pb}^{2+}$, while the least ecological threat comes from the concentrations of $\mathrm{Mn}^{2+}$.

Conclusions: The mean levels of reductions in heavy metal concentrations in pyritic mine waste after mycoremedial interventions observed in the current study clearly indicate that, in bio-sorption, P. ostreatus is more efficient in sequestering $\mathrm{Mn}^{2+} ; \mathrm{Fe}^{3+}$; and $\mathrm{Cd}^{2+}$, in that order. The oyster mushroom is less efficient in the bio-sorption of $\mathrm{Cr}^{2+}$ and $\mathrm{Fe}^{3+}$ from heavy metal polluted mine waste.

Keywords: Contamination, Mine dumps, Bioremediation, Oyster mushroom

\section{Background}

Mining is one of the main income earners of the Zimbabwean economy. It contributes up to $20 \%$ of Zimbabwe's gross domestic product. Apart from its contribution to exports, the mining industry plays an important role in providing essential mineral-based raw materials to the local manufacturing industry [1]. Over the last century the generation of overburden material has grown

*Correspondence: johnsonmasaka@yahoo.com; johnsonmasaka@gmail. com; masakaj@msu.ac.zw

1 Department of Land and Water Resources Management, Midlands State University, Private Bag 9055, Gweru, Zimbabwe

Full list of author information is available at the end of the article dramatically with the increasing demand for minerals and metals in the world market and the decreasing metal ore grades being mined in Zimbabwe. As a result, metal mining activities have generated large volumes of toxic and harmful residues for long periods at mining and processing sites [2]. Since the efficiency of the extraction process is always less than $100 \%$, a high proportion of ore that contains uneconomic material with variable amounts of metallic minerals which can be mobilized into the terrestrial environment is discarded [2-4].

Bioremediation is an innovative and promising technology available for removal and recovery of heavy 
metals from polluted environments. It involves the microbe-mediated process for clearance of contaminants [5]. The role of mushroom in biosorption of heavy metals into its biomass is well documented, and understanding its propagation on contaminated materials has numerous biotechnological implications for bioremediation of mine dump sites [6].

The microbial cell walls, which mainly consist of polysaccharides, lipids and proteins, offer many functional groups that can bind heavy metal ions, and these include carboxylate, hydroxyl, amino and phosphate groups [7]. Selection of the microbes for bioremediation of contaminated environments should be done based on an understanding of mechanisms involved in the adsorption and mobilization of heavy metals and trace elements in the soil to restore soil health [3].

With the growth of gold and nickel mining industry in the Bindura area of central Zimbabwe, there has been a considerable increase in the discharge of gold mining waste to the environment. In addition to that, the low efficiency of the mechanical and chemical gold extraction processes has caused a mine dump pile-up of discarded metalliferous mine residues, which can mobilize heavy metals into the terrestrial and aquatic environments with deleterious impacts $[2,8]$. Heavy metals can pose longterm environmental and health implications because of their non-biodegradability and persistence. In view of this, the study investigates the potential of mushroom propagated on mine dumps for the biosorption of heavy metals.

\section{Methods}

\section{Site description}

\section{Location and weather conditions}

The aim of the current study was to establish the possibility of use of oyster mushroom as a green technology for the bioremediation of mine dumps contaminated with pyritic heavy metals. The study area located in the immediate vicinity of the mining town of Bindura in central Zimbabwe $\left(17^{\circ} 18^{\prime} \mathrm{S} 31^{\circ} 20^{\prime} \mathrm{E} ; 1070 \mathrm{~m}\right.$ above sea level, Fig. 1) consists of gold and nickel mine waste and tailings dumps. Bindura town is spread over an area of $200 \mathrm{~km}^{2}$, supporting a population of 46,275 [9]. The area lies in agro-ecological region two with an annual rainfall total of $800 \mathrm{~mm}$. The seasons are characterized by rainy summers (November to April) and short dry winters (May to July). The average annual air temperature of the area is $23^{\circ} \mathrm{C}$ with an average minimum and maximum temperature of 12 and $30^{\circ} \mathrm{C}$, respectively [10].

The Bindura mining area falls under the gold belt formations (complexes of metamorphosed basaltic and andesitic lavas and sediments) which are important sources of minerals in Zimbabwe. Pyrite is the dominant sulphide of the gold bearing rocks in the geological formations [11-13].

Bindura town is sandwiched by four major gold mines (Bindura, Trojan, Freda-Rebecca and Renny; Fig. 1). Mine waste dumps were formed as a result of disposal of spoils from the open pit mines. The mine dumps are irregularly shaped and are characterized by horizontal terraces with steep edge slopes of $5-30^{\circ}$ and a depth of approximately 20-100 $\mathrm{m}$. The primary minerals are nickel, gold and platinum [11-13].
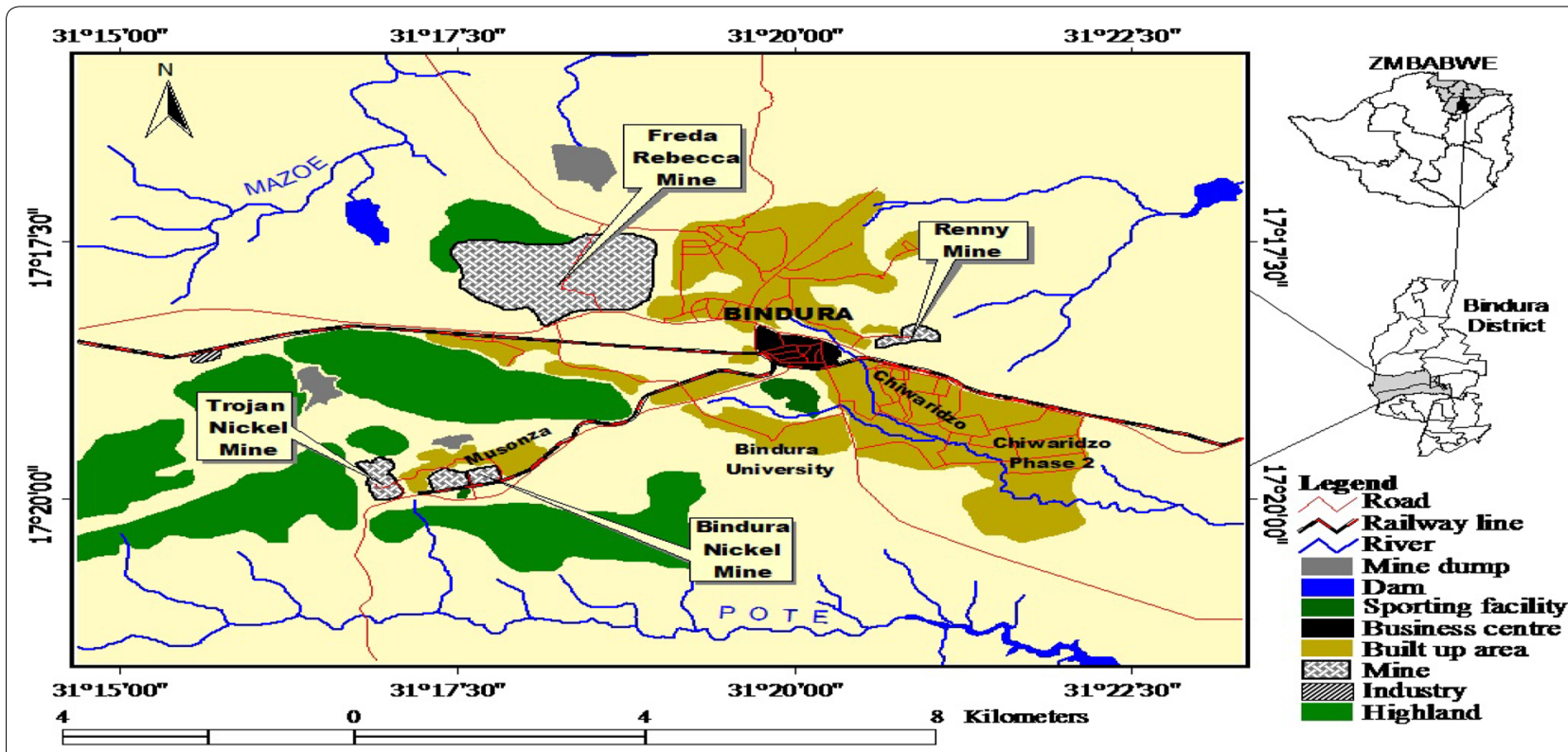

Fig. 1 Location of study sites 
The four mine dumps are located in a vast area drained by the Mazowe-Pote river systems, which is a part of the greater Zambezi river catchment in Zimbabwe (Fig. 1). The mine dumps occupy micro-catchment areas that drain north-eastwards into the Mazowe and Pote rivers. The mobilization of heavy metals from the mine dumps with comparatively steel slopes $\left(5-30^{\circ}\right)$ into the river systems has a potential of contaminating the environment in the Mazowe-Pote river system. The area has a thriving mixed farming system that supplies the metropolitans of Bindura, Chinhoyi and Harare with a variety of agricultural produce.

\section{Description of the mine dump sites bioremediation experiments \\ Collection of uncontaminated soil for comparison}

The background contaminant concentration values were obtained in soil samples collected from a virgin forest about $5 \mathrm{~km}$ upstream of the mine dump sites within the Mazowe-Pote river system (Fig. 1). The soil samples were collected from 20 randomly selected sites under forest canopy using a shovel (0-20 cm depth). The samples were thoroughly mixed by hand in sterilized gloves in a $50 \mathrm{~L}$ plastic bucket and dried under shed. Composite samples were collected from the dried soil for laboratory analyses.

\section{Identification of the mushrooms for bioremediation}

The species Pleurotus ostreatus Jacq.et Fr is a common oyster edible mushroom. It is now grown commercially in Zimbabwe and around the world for food. Oyster mushrooms can also be used industrially for mycoremediation of heavy metal-polluted environments [4]. The samples of the mushroom spawn were confirmed by a mycologist in the Biological Sciences department at the University of Zimbabwe.

\section{Preparation of the substrate and dried mushroom for the mine dump site experiments}

The wheat straw substrate for the field experiments was collected from a food oyster mushroom farmer in Harare as spent mushroom compost. The dried shredded mushroom which was used as $P$. ostreatus spawn source is a product of mushroom production at the same unit. The dried mushroom fruit was placed in shredding machine before soaking in clean water to $50 \%$ moisture content for the field trial. The wheat straw substrate was hammermilled and soaked in clean water that was mixed with formalin ( 2 parts water: 1 part formalin) for $24 \mathrm{~h}$ to eliminate wild fungus spores and bacteria. The substrate was then squeezed of its excess water to achieve $50 \%$ residual moisture content. The wheat straw substrate and shredded mushroom were then placed in separately sterilized
50 litre plastic containers and transported to the four mine dump sites for the field experiments.

\section{Experimental design and treatments}

Field experiments were employed in this study in order to determine the effectiveness of oyster mushroom as a bioremediation agent for the sequestration of pyritic heavy metals from mine dumps. The field experiments were carried out at each of the four selected mine waste dumps (Trojan, Freda-Rebecca, Renny and Bindura mines; Fig. 1).

The Latin square design was employed in the current study to control the variation in the experiments related to rows and columns in the mine dump sites. Each treatment was replicated five times. The following treatments were used in the experiments: Uncontaminated garden soil (treatment 1, control); contaminated dump site waste (treatment 2); dried oyster mushroom + contaminated dump site soil (treatment 3); sterilized wheat straw substrate + contaminated dump site soil (treatment 4); sterilized wheat straw substrate + dried oyster mushroom (mushroom spawn) + contaminated dump site soil (treatment 5).

Fifty pits arranged in the Latin square experimental design on each selected dump site were dug measuring $1 \mathrm{~m}$ by $1 \mathrm{~m}$ with a depth of $0.20 \mathrm{~m}$. The entire pit was lined with $250 \mathrm{~m} \mu$ black polyvinyl sheeting, which was at least $10 \mathrm{~cm}$ wider and longer than inside dimensions of the pit to allow for the plastic to be laid over the top of the walls by weights.

For treatment 1 (the control), randomly allocated pits were completely filled with uncontaminated virgin forest soil without any amendments. For treatment 2, the contaminated mine waste excavated from pits were returned into the respective pits without the oyster mushroom spores. In treatment 3 , half of the excavated mine waste was thoroughly mixed with an equal amount of dried shredded mushroom using a sterilized wooden stick and returned into the pit. The dried shredded mushroom was replaced with the same amount of wheat straw substrate in treatment 4 . In treatment 5 , a third on dry weight basis constituted the excavated mine waste material; a third by sterilized wheat straw substrate and a third by dried shredded mushroom (with spores) were thoroughly mixed in a sterilized plastic bin and returned into the respective dump site experimental pits.

All the replicates were irrigated with drinkable water until 50\% moisture level was achieved. Each replicate was covered with black plastic sheeting after adding the water in order to maintain constant moisture levels and development of the mushroom fruit bodies in treatments. The constant moisture level was maintained until the end of the study at 8 weeks. 


\section{Sampling and laboratory analyses}

A non-biased systematic linear sampling method was used to collect replicate pit samples for the evaluation of the concentrations of the heavy metals at the four mine waste dump sites at the beginning and end of the mine dump experiments. The pit samples collected from a depth of $0-20 \mathrm{~cm}$ for each treatment at each selected mine dump site were taken to a laboratory and dried in an oven at $450{ }^{\circ} \mathrm{C}$ for $48 \mathrm{~h}$. The concentrations of heavy metals $\left(\mathrm{Mn}^{2+}, \mathrm{Cr}^{2+}, \mathrm{Pb}^{2+}, \mathrm{Fe}^{3+}\right.$ and $\left.\mathrm{Cd}^{2+}\right)$ in the samples were determined following the procedures described by Jiang et al. 2011 [14]. The heavy metal concentrations were determined using an atomic absorption spectrophotometer Varian Spectr AA200 in acetylene-air flame with GTA 100 atomiser (Labequip, Canada). The digested samples of soil were simultaneously prepared with blank sample contents of distilled water through the complete procedure, analysed and then used for correction of the analytical signals. Working standard solutions were prepared by suitable dilution $(0.25,0.5,1,3$ and $5 \mathrm{ppm})$ of the ICP multi-element standard solution supplied by Merck Millipore (Darmstadt, Germany). The calibration was performed with a blank and standard solution samples and detection limits (LOD) were determined with a standard deviation of blank solutions. The ranges of the calibration curves were selected to match the expected concentrations of all the selected heavy metal elements of the samples studied.

The $\mathrm{pH}$ and moisture levels in the experimental pits were measured using a Kecheng Medidor-009 digital pH and moisture metre (Jiangsu Kecheng Optoelectronic, China).

The mushroom fruit bodies were harvested at the end of the experiment (at 8 weeks) and sun-dried until residual moisture was 50\%. Dried mushroom samples were analysed using an atomic absorption spectrophotometer following the procedures described by Jiang et al. 2011 [14].

\section{Germination percentage test for in situ experiment}

Replicate pits at each dump site were planted with sugar bean seed (Phaseolus vulgaris L.) after the remediation experimental period had lapsed. An in-row spacing of $10 \mathrm{~cm}$ by an inter-row of $30 \mathrm{~cm}$ was used for planting the seeds and each replicate was planted with 24 bean seeds ( 8 seeds in the in-row $\times 3$ seeds in the inter-row lines). The planted plots were kept moist and analysed for germination at 7 days after sowing.

\section{Single-factor and comprehensive heavy metal pollution assessment at mine dump sites}

The single-factor index method was employed to evaluate the pollution of the selected heavy metals, but research has shown that the single-factor index cannot express accurately the comprehensive impact caused by each kind of heavy metals. The Nemerow index method takes not only the extreme value but also the environmental quality index based on weighted multi-factors. The method can reflect the degree of soil pollution caused by various heavy metals. To assess the degree of heavy metal contamination, the pollution index (PI) for each heavy metal and Nemerow integrated pollution index (NIPI) [15] for the five heavy metals $\mathrm{Mn}^{2+}, \mathrm{Cr}^{2+}, \mathrm{Pb}^{2+}, \mathrm{Fe}^{3+}$ and $\mathrm{Cd}^{2+}$ ) were attributed to each sample. The PI was determined as follows:

$$
\mathrm{PI}=\frac{C_{i}}{S_{i}},
$$

where PI is the pollution index of the pollutant $i$ at the mine dump site; $C_{i}$ is the measured concentration value of the heavy element $i$; $S_{i}$ is the concentration value of the respective metal in the uncontaminated virgin forest soil. In the current study, the Nemerow integrated (multi-factor) pollution index (NIPI) was expressed as

$$
\mathrm{NIPI}=\frac{\sqrt{\left(P_{i}^{2} \max +P_{i}^{2} \text { ave }\right)}}{2},
$$

where NIPI is Nemerow integrated pollution index at location $i ; P_{i}$ max and $P_{i}$ ave represent the maximum and average values of PI, respectively. Based on Nemerow multi-factor pollution index, the environmental quality is divided into five levels shown in Table 1.

The current research employed the potential $\left(E_{\mathrm{r}}^{i}\right)$ and comprehensive potential (RI) ecological risk indices described in detail by Hakanson [16] and Douay et al. [17] to evaluate the potential ecological risk of heavy metals. In order to establish the $E_{\mathrm{r}}^{i}$ and RI values, the single heavy metal pollution index was computed using the following model:

$$
C_{\mathrm{f}}^{i}=\frac{C_{\mathrm{D}}^{i}}{C_{\mathrm{R}}^{i}},
$$

where $C_{\mathrm{f}}^{i}$ is the contamination factor; $C_{\mathrm{D}}^{i}$ is the degree of contamination (that is the quantified value of a particular heavy metal in contaminated material); $C_{\mathrm{R}}^{i}$ is reference value, which is the background value of a particular heavy metal of virgin forest soil.

The comprehensive potential ecological risk index (RI) was calculated using the following equations:

$$
\begin{aligned}
& E_{\mathrm{r}}^{i}=T_{\mathrm{f}}^{i} \times C_{\mathrm{f}}^{i} \\
& \mathrm{RI}=\sum_{i=1}^{n} E_{r}^{i},
\end{aligned}
$$


Table 1 Nemerow multi-factor pollution, potential and comprehensive ecological indices. Source: Hakanson [16] and Douay et al. [17]

\begin{tabular}{ll}
\hline Nemerow multi-factor pollution index, NIPI \\
\hline NIPI ranges & Pollution grades \\
\hline$\leq 0.7$ & Clean \\
$0.7<\mathrm{NIPI} \leq 1$ & Cautionary \\
$1<\mathrm{NIPI} \leq 2$ & Light pollution \\
$2<\mathrm{NIPI} \leq 3$ & Medium pollution \\
$\mathrm{NIPI}>3$ & Heavy pollution \\
\hline
\end{tabular}

Potential $\left(E_{\mathrm{r}}^{i}\right)$ and comprehensive (RI) ecological harm indices rating for the heavy metal

\begin{tabular}{lll}
\hline$E_{\mathbf{r}}^{i}$ range & RI range & Ecological pollution grades \\
\hline$<40$ & $<150$ & Light ecological risk \\
$40-79$ & $150-299$ & Middle ecological risk \\
$80-159$ & $300-600$ & Strong ecological risk \\
$160-320$ & $>600$ & Very strong ecological risk \\
$>320$ & $<150$ & Extremely strong ecological risk \\
\hline
\end{tabular}

where $E_{\mathrm{r}}^{i}$ is the potential ecological risk coefficient; $T_{f}^{\mathrm{i}}$ is the biological toxic factor of a single element, which is determined for $\mathrm{Mn}=\mathrm{Fe}=\mathrm{Cr}=2, \mathrm{~Pb}=5$ and $\mathrm{Cd}=30$ [16]. The potential $\left(E_{\mathrm{r}}^{i}\right)$ and comprehensive potential (RI) ecological risk ratings are divided into five levels shown in Table 1.

\section{Statistical analyses}

Treatment effects on heavy metal concentrations in mine waste and oyster mushroom fruit bodies and trends in mine dump waste $\mathrm{pH}$ were performed using Generalized One-Way ANOVA of completely randomized blocks in Latin square design [18]. Flux data on concentrations of heavy metals were log-transformed if needed, to normalize the distributions before the statistical analysis. Differences between treatment means were considered significant at $p \leq 0.05$ as determined by Fisher's protected least significant difference test.

\section{Results and discussion}

\section{Concentrations of heavy metals and $\mathrm{pH}$ in mine dumps} after growing oyster mushroom

The mine dump waste at each of the four study sites in central Zimbabwe (Fig. 1) was characterized by considerably high heavy metal concentrations (Fig. 2), low organic matter content (Table 1) and high levels of waste acidity (low pH values, Fig. 3). Compared with the background values of heavy metals in virgin forest soil, concentrations of $\mathrm{Mn}^{2+}, \mathrm{Cr}^{2+}, \mathrm{Pb}^{2+}, \mathrm{Fe}^{3+}$ and $\mathrm{Cd}^{2+}$ in mine dump waste were substantially $(p<0.05)$ enriched in the study sites (Fig. 2). The propagation of oyster mushroom for the bioremediation of heavy metal pollution in pyritic mine dump waste at the selected four mining sites significantly $(p<0.05)$ reduced the concentrations of the heavy metals in the mine dump waste at the end of the study (Fig. 2). Mean concentrations of the heavy metals (Fig. 2) and $\mathrm{pH}$ (Fig. 3) in treatment five plots were comparatively similar to those recorded in the control replicates at the end of the experiment. The differences between $\mathrm{pH}$ values for the control plots (uncontaminated virgin forest soil) and the plots treated with of P. ostreatus (treatment 5) in the heavy metal-contaminated mine waste were $0.5-0.9 \mathrm{pH}$ units.

All experimental plots on pyritic mine dump waste that did not receive viable $P$. ostreatus spawn were considerably acidic with $\mathrm{pH}$ values ranging between 1 and 3.2 which were significantly $(p<0.05)$ lower than the $\mathrm{pH}$ values of unpolluted virgin forest soil $(\mathrm{pH} 5.7-6.0)$ (Fig. 3). Acidity in plots that were treated with wheat straw substrate, dried oyster mushroom and water applications (treatment 5) consistently approached neutral $\mathrm{pH}$ values after declining by $52-84 \%$ when compared with experimental pits without oyster mushroom growth over 8 weeks.

The results indicate that the mining activities at the four study sites in the Bindura mining region of Zimbabwe have the potential to mobilize significant amounts of heavy metals into surface environments of the MazowePote river catchments (Fig. 1). In the current study, the possibility of an accumulation of heavy metals in crop plants on arable lands around the Bindura area is of great concern due to the probability of food contamination through the soil-plant root interface [15].

The variations in the concentrations of the heavy metals in the mine dump waste for the various experimental pits are attributed to the heavy metal biosorption capacity of the mushroom biomass. In a related study on concentrations of heavy metals in species of mushrooms growing in the East Black Sea region, Demirbas [19] reported a higher capability of mushroom to bio-accumulate heavy metal contaminants in their fruit bodies. The P. ostreatus is suspected to have initially exhibited a marked tolerance towards the elevated concentrations of the heavy metals

(See figure on next page.)

Fig. 2 Concentrations of heavy metals in mine dump waste before and after treatment with oyster mushroom. Trt treatment, A Trt after treatments, $B /$ Trt before treatments, LSL local safe limits, Lsd least significant difference, CV coefficient of variation 

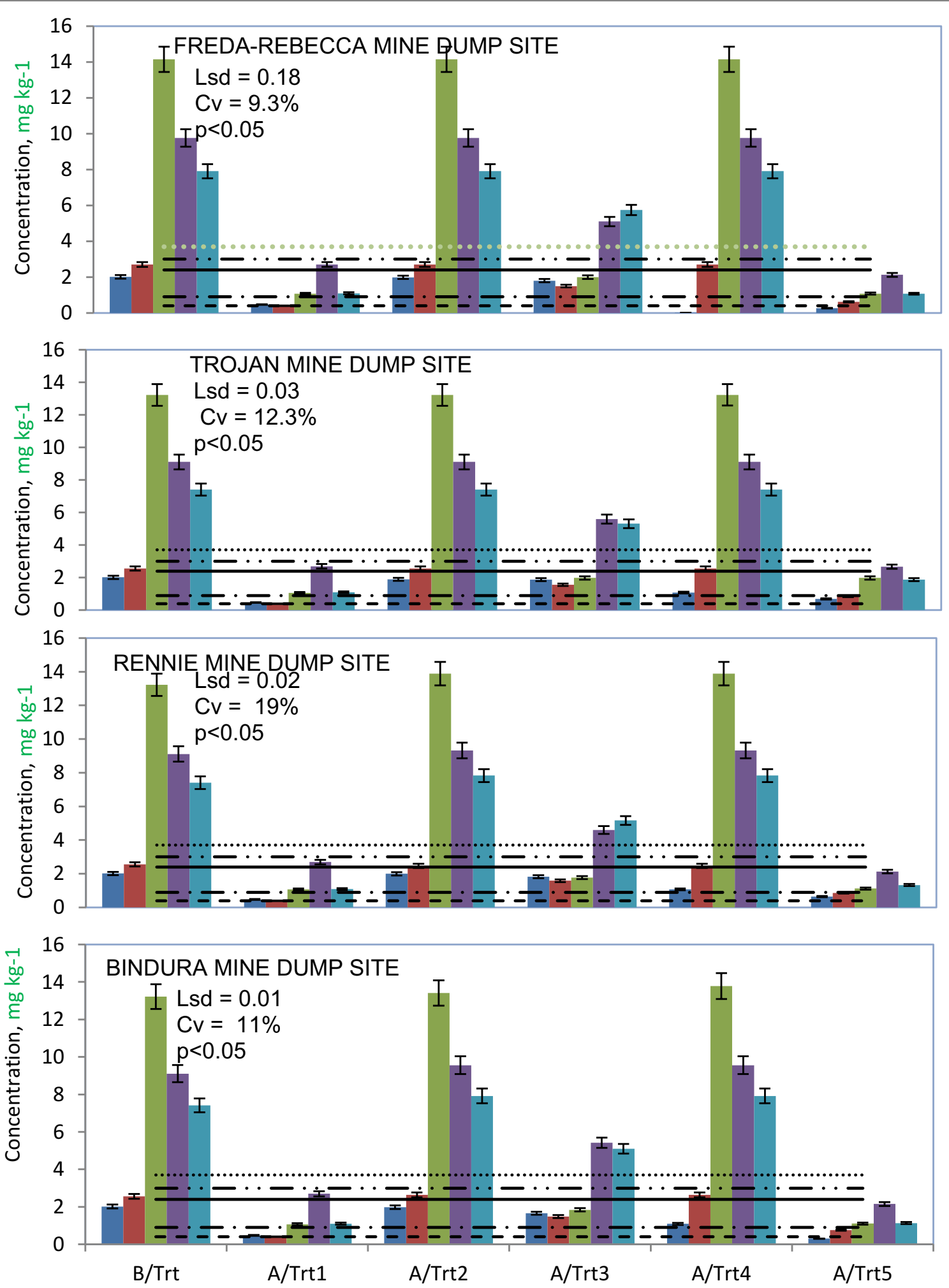

Experimental treatments
Mn
$\mathrm{Pb}$
$\mathrm{Fe}$
$\mathrm{Cd}$
$\longrightarrow$ LSLMn
- - - LSLCr
- - LSLPb
- LSLFe
$-\cdots-\operatorname{LSLCd}$ 


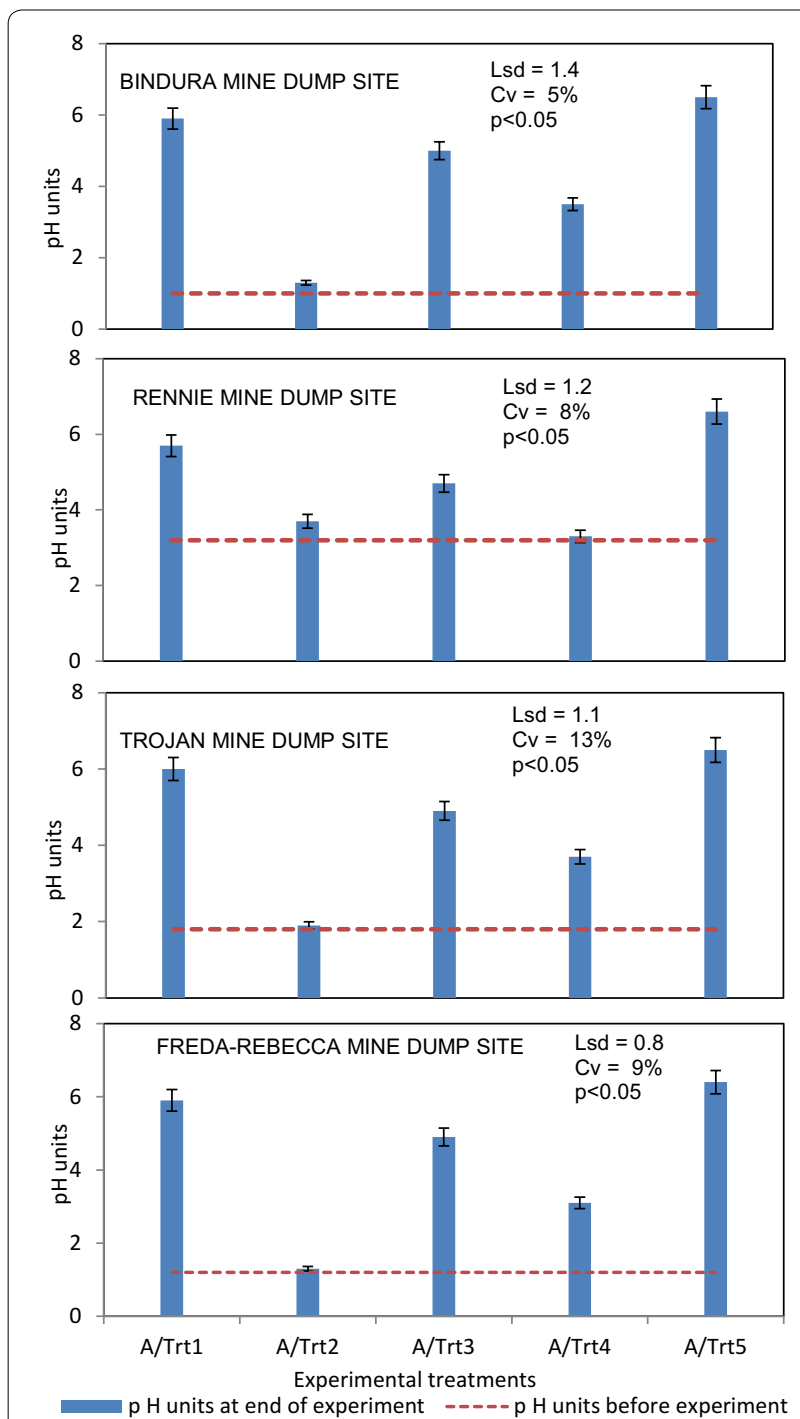

Fig. $3 \mathrm{pH}$ units in mine dump waste before and after bioremediation with oyster mushroom

(Fig. 2) and adverse conditions of high acidity (Fig. 3) in the mine dump waste recorded in this study. Related studies on mycoremediation have indicated that contaminant heavy metals can be biosorbed by mushroom bodies at binding sites found in the cellular structure [20]. In the current study, it is suggested that among the various reactive compounds associated with fungal cell walls, the extracellular polymeric substances reported by Gutierrez et al. [21] were of particular importance and are known to have significant effects on acid-base properties and metal adsorption [22-24]. The considerable reduction in the concentrations of heavy metals in the experimental plots that successfully supported vigorous growth of the basidiomycetes (Fig. 4) clearly implies that the investigated mushroom species is an efficient bio-exlusor of

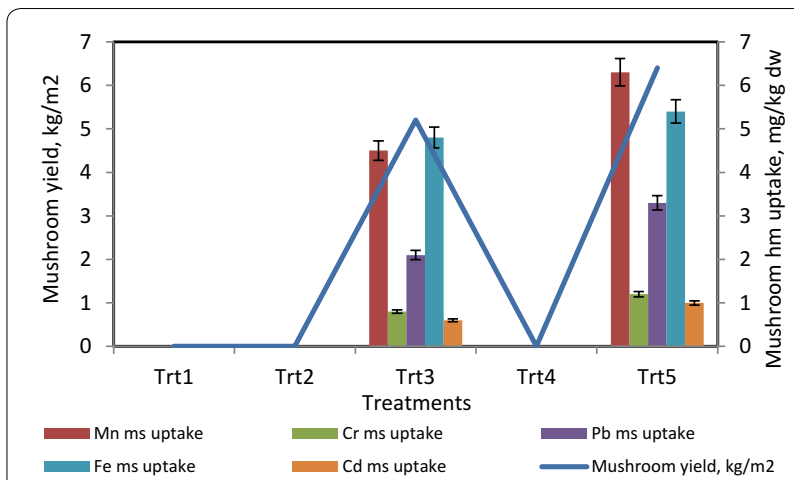

Fig. 4 Oyster mushroom yield and heavy metal uptake. Trt treatment, $m s$ mushroom, $h m$ heavy metal

$\mathrm{Mn}^{2+}, \mathrm{Cr}^{2+}, \mathrm{Pb}^{2+}, \mathrm{Fe}^{3+}$ and $\mathrm{Cd}^{2+}$ from their growing environments.

Considerable reductions of the heavy metal concentrations (Fig. 2) in the experimental pits that supported successful colonization and growth of the oyster mushroom coincided with comparatively near neutral $\mathrm{pH}$ values and had the highest mushroom fruit body yield and heavy metal uptake (Fig. 4). This clearly demonstrated that the successful propagation of the oyster mushroom in the mine dump waste has bioremediative outcomes in the decontamination of mine overburden material. It has been reported previously that $\mathrm{pH}$ is one of the variables influencing the bioavailability and transport of heavy metals in the waste, and heavy metal mobility decreases substantially with increasing soil $\mathrm{pH}$ due to the precipitation of hydroxides, carbonates or the formation of insoluble organic complexes [25]. Consequently, dump site pits that received viable oyster mushroom spawn and ground wheat straw substrate recorded significant $\mathrm{pH}$ increases accompanied by considerable reductions in the concentrations of the mobile heavy metals (Fig. 2).

The applications of shredded mushroom to pyritic mine waste without wheat straw substrate in treatment 3 resulted in smaller, though significant $(p<0.05)$, reductions in the mean levels of the pyritic heavy metals in the mine waste at all four sites. The absence of the wheat straw substrate in the use of $P$. ostreatus as bioremediation material for the biosorption of pyritic heavy metals in mine dump waste (treatment 3 ), when compared with the reductions in treatment 5 , brought down the content of the selected heavy metals (except for $\mathrm{Pb}^{2+}$ whose concentration declined by $85 \%$ ) by much smaller values of $0.2 \mathrm{mg} \mathrm{kg}^{-1}$ (11\%), $1.2 \mathrm{mg} \mathrm{kg}^{-1}(45 \%), 4.9 \mathrm{mg} \mathrm{kg}^{-1}$ (48\%), $2.3 \mathrm{mg} \mathrm{kg}^{-1}(27 \%)$ for $\mathrm{Mn}^{2+}, \mathrm{Cr}^{2+}, \mathrm{Fe}^{3+}$ and $\mathrm{Cd}^{2+}$, respectively, at the end of the experiment (Fig. 2).

The mean levels of reductions in heavy metal concentrations in pyritic mine waste after mycoremedial interventions observed in the current study clearly indicate that, in biosorption, $P$. ostreatus is more efficient in 
sequestering $\mathrm{Mn}^{2+}(98 \%), \mathrm{Fe}^{3+}(93 \%)$ and $\mathrm{Cd}^{2+}(88 \%)$, in that order. The biosorption of $\mathrm{Cr}^{2+}(79 \%)$ and $\mathrm{Fe}^{3+}(78 \%)$ from heavy metal-polluted mine waste (Fig. 2) is less efficient. The $\mathrm{Mn}^{2+}, \mathrm{Fe}^{3+}, \mathrm{Cd}^{2+}$ biosorption efficiency of P. ostreatus observed at the four study sites was further confirmed by the current results when concentrations of the respective heavy metals at the end of the experiment were compared with local safe limits (LSL, locally accepted safe concentration limits for a heavy metal) of the heavy metal concentrations in soil (Fig. 2). In this respect, the oyster mushroom's capacity as a biosorbent of $\mathrm{Mn}^{2+}, \mathrm{Fe}^{3+}$ and $\mathrm{Cd}^{2+}$ from pyritic mine waste dumps was re-confirmed by the fact that their concentrations after bioremediation (treatment 5) at the four study sites were lower than the LSL by $1.92 \mathrm{mg} \mathrm{kg}^{-1}(20 \%)$, $1.43 \mathrm{mg} \mathrm{kg}^{-1}$ (39\%) and $1.65 \mathrm{mg} \mathrm{kg}^{-1}$ (55\%), respectively.

Mushroom substrate is a kind of lignocellulose material which supports the growth, development and fruiting of mushroom [2, 4, 20]. Previous studies by Demirbas [19], Gavrilescu [6], Kojta and Zhang [26] have reported that an ideal substrate will contain enough nitrogen and carbohydrate for rapid mushroom growth. In the current study, substrate conditions present in treatment 3 lacked the carbohydrate component necessary for the supply of energy and organic carbon for mushroom biomass synthesis.

The propagation of $P$. ostreatus in environments that supplied the necessary conditions for normal growth of the mushroom (mushroom + substrate + contaminated soil) was able to bring down the initial high concentrations of pyritic heavy metals. The application of mushroom + substrate to heavy metal-polluted pyritic mine waste (treatment 5), when compared with the initial levels, reduced considerably the concentrations of mobile heavy metals in the waste by $1.2 \mathrm{mg} \mathrm{kg}^{-1}$ (98\%), $2.0 \mathrm{mg} \mathrm{kg}^{-1}$ (79\%), $13.1 \mathrm{mg} \mathrm{kg}^{-1}$ (93\%), $7.7 \mathrm{mg} \mathrm{kg}^{-1}$ (78\%) and $6.5 \mathrm{mg} \mathrm{kg}^{-1}$ (88\%) for $\mathrm{Mn}^{2+}, \mathrm{Cr}^{2+}, \mathrm{Pb}^{2+}, \mathrm{Fe}^{3+}$ and $\mathrm{Cd}^{2+}$, respectively, at the end of the study.
Although some heavy metals like $\mathrm{Mn}^{2+}, \mathrm{Cr}^{2+}, \mathrm{Fe}^{3+}$ and $\mathrm{Cd}^{2+}$ are required for growth of plants in trace amounts, they may damage plants if present beyond their maximum permissible limits [27]. Recent studies have shown that heavy metal uptake by the oyster mushroom into the cell across the cell membrane as intracellular uptake is dependent on the cell metabolism [3,28]. This type of heavy metal uptake from mine dump waste by the oyster mushroom requires energy expenditure by the mushroom cells. Since the mushroom is heterotrophic, it uses the organic substrate as the source of energy. While sunlight provides an energy source for plants, mushrooms derive all of their energy and growth materials from their growth medium, through biochemical decomposition processes. Consequently, combinations of the viable mushroom spawn in dried mushroom and the wheat straw as source of energy for the active uptake of the heavy metals from mine dump waste in treatment 5 experimental pits were followed by considerable reductions of the heavy metal concentrations to be within safe limits (Fig. 2). The application of $P$. ostreatus as a biosorbent is not only dependent on its biosorptive capacity, but also how easy it is to regenerate and reuse oyster mushroom biomass. However, the intracellular heavy metal absorption by the mushroom cells can only mean that the absorbed heavy metals are disposed off through destructive treatment.

Treatments that received the substrate + contaminated waste showed smaller biosorption capacity of the heavy metals (treatment 3 ). The substrate acted as the source of nutrients for the indigenous soil fungal strains at the respective sites for the biosorption of the heavy metals. Essentially, the substrate is the organic matter (Table 2) that helps in the promotion of bio-adsorption of the heavy metals on the surface of organic matter [22]. However, the role of substrate alone without the use of the mushroom (P. ostreatus) was not significant enough to cause a considerable

Table 2 Organic matter content in mine dump waste before and after treatment with oyster mushroom

\begin{tabular}{|c|c|c|c|c|c|c|c|c|}
\hline \multirow[t]{3}{*}{ Trts } & \multicolumn{8}{|c|}{ Organic matter content in mine dump waste before and after treatments (\%) } \\
\hline & \multicolumn{2}{|c|}{ Freda-Rebecca mine } & \multicolumn{2}{|c|}{ Trojan mine } & \multicolumn{2}{|c|}{ Renny mine } & \multicolumn{2}{|c|}{ Bindura mine } \\
\hline & Before trt & After trt & Before trt & After trt & Before trt & After trt & Before trt & After trt \\
\hline 1 & $9.3^{\mathrm{a}}$ & $9.4^{\mathrm{a}}$ & $9.3^{\mathrm{a}}$ & $9.3^{\mathrm{a}}$ & $9.4^{\mathrm{a}}$ & $9.4^{\mathrm{a}}$ & $9.3^{\mathrm{a}}$ & $9.3^{\mathrm{a}}$ \\
\hline 2 & $3.2^{\mathrm{b}}$ & $3.4^{b}$ & $3.1^{\mathrm{b}}$ & $3.2^{b}$ & $3.4^{b}$ & $3.3^{b}$ & $3.1^{\mathrm{b}}$ & $3.2^{b}$ \\
\hline 3 & $3.1^{\mathrm{b}}$ & $5.3^{c}$ & $3.3^{b}$ & $5.8^{c}$ & $3.2^{b}$ & $6.1^{c}$ & $3.1^{\mathrm{b}}$ & $5.9^{c}$ \\
\hline 4 & $3.3^{b}$ & $4.8^{d}$ & $3.4^{\mathrm{b}}$ & $4.7^{d}$ & $3.1^{\mathrm{b}}$ & $4.9^{d}$ & $3.0^{\mathrm{b}}$ & $4.5^{\mathrm{d}}$ \\
\hline 5 & $3.2^{b}$ & $8.1^{\mathrm{e}}$ & $3.3^{b}$ & $7.8^{e}$ & $3.2^{b}$ & $7.9^{e}$ & $3.1^{\mathrm{b}}$ & $7.8^{e}$ \\
\hline Lsd & 0.5 & 0.4 & 0.7 & 1.5 & 0.8 & 1.1 & 0.6 & 1.2 \\
\hline CV (\%) & 11.0 & 7.0 & 13.0 & 4.0 & 10.0 & 9.0 & 5.0 & 8.0 \\
\hline
\end{tabular}

Trt treatments, Lsd least significant difference, $C V$ coefficient of variation

Superscripts indicate mean separations that are significant 
decrease in the heavy metal concentration levels in replicate pits that received substrate + contaminated (treatment 3).

\section{Local safe limits, mushroom yield and uptake of heavy metals after bioremediation}

Except for $\mathrm{Mn}^{2+}$, results have shown that the concentrations of the selected heavy metals $\left(\mathrm{Mn}^{2+}, \mathrm{Cr}^{2+}, \mathrm{Pb}^{2+}\right.$, $\mathrm{Fe}^{3+}$ and $\mathrm{Cd}^{2+}$ ) in the pyritic mine dump waste before the introduction of the bioremediations were consistently higher than the recommended LSL in soils (Fig. 2). Mean levels of the pyritic heavy metals in the mine dump waste were $2.2 \mathrm{mg} \mathrm{kg}^{-1}$ (5 times), $12.6 \mathrm{mg} \mathrm{kg}^{-1}$ (21 times), $5.4 \mathrm{mg} \mathrm{kg}^{-1}$ (3 times) and $4.4 \mathrm{mg} \mathrm{kg}^{-1}$ (2 times) in excess of the recommended LSL for $\mathrm{Cr}^{2+}, \mathrm{Pb}^{2+}, \mathrm{Fe}^{3+}$ and $\mathrm{Cd}^{2+}$ concentrations in mine waste before mycoremediation, respectively. In this study, mean concentrations of pyritic heavy metals in the mine dump material rated against the recommended LSL before mycoremediation followed the trend $\mathrm{Pb}^{2+}>\mathrm{Cr}^{2+}>\mathrm{Fe}^{3+}>\mathrm{Cd}^{2+}$.

If untreated, the heavy metal contaminants are able to infiltrate deep and pollute the groundwater as well as the surface water [2, 17, 29]. Heavy metals in the soil may subsequently enter the human food web through plants and can constitute some risk to the ecosystem as they tend to bio-accumulate and can be transferred from one food chain to another in the local Mazowe-Pote catchment area (Fig. 1) and beyond.

Results in Fig. 4 show that mushroom fruit body yield dynamics consistently follow trends observed in the biosorption of the selected heavy metals in treatments that received the complete conditions for the successful colonization and growth of P. ostreatus (treatment 5). Analyses of the results (Fig. 4) have consistently reconfirmed the trend that the macrofungus is a more efficient biosorbent of $\mathrm{Mn}^{2+}$ and $\mathrm{Fe}^{3+}$ when compared with the absorption of other heavy metals from polluted mine waste dumps. Current study results have indicated that heavy metal sequestration by $P$. ostreatus differed significantly $(p>0.05)$ across the treatments.
The bioremediation of the pyritic mine dump material through propagation of $P$. ostreatus on the waste in treatment 5 substantially reduced the content of the heavy metals to almost the same levels as those found in the uncontaminated virgin forest soil (Fig. 2). Previous studies by Aydinalp and Marinova [30] have concluded that mushroom biomass accumulations and various environmental factors such as $\mathrm{pH}$ (Fig. 3), organic matter (Table 2), type of substrate, geochemistry of substrate and distance from the source of pollution can affect the metal content in mushrooms.

\section{Organic matter content at mine dump site before and after bioremediation}

The propagation of oyster mushroom on mine dump waste and wheat straw substrate considerably $(p<0.05)$ increased the accumulation of organic matter in the waste (Table 2). When compared with the control (organic matter in virgin forest soil), the content of organic matter in the waste of the pits that were successfully colonized by $P$. ostreatus (treatment 5 ) differed by only 1.4 percentage points (9.3 and $7.9 \%$ organic matter content, respectively). Fairly low content of organic matter $(3.1-3.4 \%)$ was recorded consistently in replicates that were not colonized by the myco-fungus (treatment 2).

\section{Pollution rating for a single heavy metal at mine dump sites}

A quantitative analysis of single heavy metal pollution index was conducted at each study site using the Nemerow integrated pollution index (NIPI, Eq. 2) values. A comparative analysis of the data presented in Tables 3, 4 and 5 shows that the NIPI values in the mine dump waste were highly dependent $(\mathrm{p}<0.05)$ on the colonization and growth of the mushroom. The NIPI values for $\mathrm{Mn}^{2+}$, $\mathrm{Cr}^{2+}, \mathrm{Pb}^{2+}, \mathrm{Fe}^{3+}$ and $\mathrm{Cd}^{2+}$ varied considerably between treatment replicates after the employment of various combinations of $P$. ostreatus, organic substrate and the contaminated mine dump material (Tables 4,5 ). The NIPI values fell within the ranges of uncontaminated to heavy pollution. The lowest NIPI values of $0.11-1.65$ were

Table 3 Nemerow pollution index (NIPI), potential $\left(E_{r}^{i}\right)$ and comprehensive (RI) ecological harm indices before bioremediation

\begin{tabular}{|c|c|c|c|c|c|c|c|c|c|c|c|c|}
\hline \multirow[t]{2}{*}{ Heavy metal } & \multicolumn{3}{|c|}{ Trojan mine } & \multicolumn{3}{|c|}{ Freda-Rebecca mine } & \multicolumn{3}{|c|}{ Renny mine } & \multicolumn{3}{|c|}{ Bindura mine } \\
\hline & NIPI & $E_{\mathrm{r}}^{i}$ & RI & NIPI & $E_{\mathrm{r}}^{i}$ & RI & NIPI & $E_{\mathrm{r}}^{i}$ & $\mathbf{R} \mathbf{I}$ & NIPI & $E_{\mathrm{r}}^{i}$ & RI \\
\hline $\mathrm{Mn}^{2+}$ & 0.9 & 46.0 & 170.0 & 0.8 & 45.0 & 174.0 & 0.9 & 44.0 & 171.0 & 0.9 & 43.0 & 172.0 \\
\hline $\mathrm{Cr}^{2+}$ & 3.2 & 60.0 & 289.0 & 3.6 & 62.0 & 286.0 & 3.0 & 63.0 & 290.0 & 3.4 & 60.0 & 278.0 \\
\hline $\mathrm{Pb}^{2+}$ & 4.6 & 170.0 & 659.0 & 4.9 & 174.0 & 653.0 & 4.7 & 172.0 & 658.0 & 4.5 & 175.0 & 662.0 \\
\hline $\mathrm{Fe}^{3+}$ & 4.1 & 90.0 & 455.0 & 3.9 & 89.0 & 462.0 & 3.8 & 91.0 & 453.0 & 3.7 & 90.0 & 458.0 \\
\hline $\mathrm{Cd}^{2+}$ & 2.6 & 100.0 & 356.0 & 2.4 & 103.0 & 358.0 & 2.5 & 102.0 & 360.0 & 2.6 & 100.0 & 355.0 \\
\hline
\end{tabular}


Table 4 Nemerow indices after bioremediation at Trojan and Freda-Rebecca mine dump sites

\begin{tabular}{|c|c|c|c|c|c|c|c|c|c|c|}
\hline \multirow[t]{2}{*}{ Trt } & \multicolumn{5}{|c|}{ Trojan mine } & \multicolumn{5}{|c|}{ Freda-Rebecca mine } \\
\hline & $\mathrm{Mn}^{2+}$ & $\mathrm{Cr}^{2+}$ & $\mathrm{Pb}^{2+}$ & $\mathrm{Fe}^{3+}$ & $\mathrm{Cd}^{2+}$ & $\mathrm{Mn}^{2+}$ & $\mathrm{Cr}^{2+}$ & $\mathrm{Pb}^{2+}$ & $\mathrm{Fe}^{3+}$ & $\mathrm{Cd}^{2+}$ \\
\hline Trt1 & - & - & - & - & - & - & - & - & - & - \\
\hline Trt2 & $0.83^{\mathrm{a}}$ & $6.78^{\mathrm{a}}$ & $15.72^{\mathrm{a}}$ & $2.63^{\mathrm{a}}$ & $2.64^{\mathrm{a}}$ & $0.81^{\mathrm{a}}$ & $6.76^{\mathrm{a}}$ & $15.42^{\mathrm{a}}$ & $2.66^{\mathrm{a}}$ & $2.71^{\mathrm{a}}$ \\
\hline Trt3 & $0.45^{b}$ & $3.75^{\mathrm{b}}$ & $2.22^{b}$ & $1.38^{\mathrm{b}}$ & $1.91^{\mathrm{b}}$ & $0.48^{\mathrm{b}}$ & $3.74^{b}$ & $2.26^{\mathrm{b}}$ & $1.39^{b}$ & $1.79^{b}$ \\
\hline Trt4 & $0.68^{\mathrm{a}}$ & $6.78^{\mathrm{a}}$ & $15.72^{\mathrm{a}}$ & $2.64^{\mathrm{a}}$ & $2.64^{\mathrm{a}}$ & $0.74^{\mathrm{a}}$ & $6.73^{\mathrm{a}}$ & $15.64^{\mathrm{a}}$ & $2.43^{\mathrm{a}}$ & $2.60^{\mathrm{a}}$ \\
\hline Trt5 & $0.11^{d}$ & $1.55^{\mathrm{d}}$ & $1.20^{\mathrm{d}}$ & $0.58^{c}$ & $0.36^{c}$ & $0.17^{d}$ & $1.62^{c}$ & $1.30^{\mathrm{d}}$ & $0.59^{b}$ & $0.38^{c}$ \\
\hline Lsd (5\%) & 0.18 & 1.91 & 0.80 & 0.20 & 0.46 & 0.32 & 1.98 & 0.56 & 0.43 & 1.25 \\
\hline $\mathrm{Cv} \%$ & 9.80 & 3.60 & 5.20 & 7.10 & 4.30 & 5.20 & 4.20 & 8.30 & 8.20 & 9.10 \\
\hline
\end{tabular}

Superscripts indicate mean separations that are significant

Table 5 Nemerow indices after bioremediation at Renny and Bindura mine dump sites

\begin{tabular}{|c|c|c|c|c|c|c|c|c|c|c|}
\hline \multirow[t]{2}{*}{ Trt } & \multicolumn{5}{|c|}{ Renny mine } & \multicolumn{5}{|c|}{ Bindura mine } \\
\hline & $\mathrm{Mn}^{2+}$ & $\mathrm{Cr}^{2+}$ & $\mathrm{Pb}^{2+}$ & $\mathrm{Fe}^{3+}$ & $\mathrm{Cd}^{2+}$ & $\mathrm{Mn}^{2+}$ & $\mathrm{Cr}^{2+}$ & $\mathrm{Pb}^{2+}$ & $\mathrm{Fe}^{3+}$ & $\mathrm{Cd}^{2+}$ \\
\hline Trt1 & - & - & - & - & - & - & - & - & - & - \\
\hline Trt2 & $0.79^{\mathrm{a}}$ & $6.72^{\mathrm{a}}$ & $15.71^{\mathrm{a}}$ & $2.65^{\mathrm{a}}$ & $2.69^{\mathrm{a}}$ & $0.76^{\mathrm{a}}$ & $6.81^{\mathrm{a}}$ & $15.43^{\mathrm{a}}$ & $2.56^{\mathrm{a}}$ & $2.70^{a}$ \\
\hline Trt3 & $0.44^{\mathrm{b}}$ & $3.75^{\mathrm{b}}$ & $2.26^{b}$ & $1.28^{\mathrm{b}}$ & $1.93^{b}$ & $0.42^{\mathrm{b}}$ & $3.78^{b}$ & $2.27^{b}$ & $1.36^{\mathrm{b}}$ & $1.78^{b}$ \\
\hline Trt4 & $0.67^{\mathrm{a}}$ & $6.79^{a}$ & $15.74^{\mathrm{a}}$ & $2.63^{\mathrm{a}}$ & $2.66^{\mathrm{a}}$ & $0.66^{\mathrm{a}}$ & $6.75^{\mathrm{a}}$ & $15.59^{\mathrm{a}}$ & $2.53^{\mathrm{a}}$ & $2.64^{\mathrm{a}}$ \\
\hline Trt5 & $0.11^{c}$ & $1.54^{c}$ & $1.21^{\mathrm{c}}$ & $0.68^{c}$ & $0.38^{c}$ & $0.18^{c}$ & $1.65^{c}$ & $1.33^{c}$ & $0.57^{c}$ & $0.39^{c}$ \\
\hline Lsd (5\%) & 0.16 & 1.89 & 0.95 & 0.44 & 0.93 & 0.20 & 0.25 & 0.40 & 0.38 & 0.25 \\
\hline Cv\% & 4.40 & 7.00 & 6.40 & 6.60 & 9.10 & 4.70 & 5.20 & 8.10 & 7.10 & 8.00 \\
\hline
\end{tabular}

Superscripts indicate mean separations that are significant

recorded in the replicates that received the bioremedial combinations of sterilized wheat straw substrate + dried oyster mushroom (treatment 5), indicating heavy metal contamination reduction to levels in ranges of clean to light pollution. When NIPI values for replicates in treatment 2 (contaminated waste without $P$. ostreatus) were compared with NIPI values in treatment 5 , results indicated that the propagation of $P$. ostreatus on pyritic mine dump waste reduces pollution threats of $\mathrm{Cr}^{2+}$ and $\mathrm{Pb}^{2+}$. The application of $P$. ostreatus as bioremediation material reduces the individual heavy metal pollution threat in mine dump waste from medium pollution (2.63-2.64) to clean and uncontaminated waste $(0.36-0.58)$ for the $\mathrm{Fe}^{3+}$ and $\mathrm{Cd}^{2+}$ contaminants (Tables 4, 5).

The largest reduction in the NIPI was observed in the concentration of $\mathrm{Pb}^{2+}$ in the mine waste where initial average NIPI of 15.57 (indicating heavy pollution levels) at the four mine dump sites dropped to 1.26 (light pollution level) after bioremediation using P. ostreatus (Tables 4, 5). The results of the current study have shown that the use of $P$. ostreatus at mine dump site reduces the heavy metal pollution degrees in the order $\mathrm{Cr}^{2+}>\mathrm{Pb}^{2+}>\mathrm{Fe}^{3+}>\mathrm{Cd}^{2+}>\mathrm{Mn}^{2+}$. In ascending order, this trend was reversed in the order
$\mathrm{Mn}^{2+}<\mathrm{Cd}^{2+}<\mathrm{Fe}^{3+}<\mathrm{Pb}^{2+}<\mathrm{Cr}^{2+}$ in the NIPI indices after successful propagation of the oyster mushroom in the waste (treatment 5). This implies that the greatest pollution threat from a single heavy metal was posed by $\mathrm{Cr}^{2+}$ after treatment of mine waste with oyster mushroom. This clearly implies that the vigorous biosorption of a particular heavy metal $\left(\mathrm{Cr}^{2+}\right)$ by $P$. ostreatus may not necessarily be followed by the detoxification levels of $\mathrm{Cr}^{2+}$ into the clean ranges of pollution rating.

It has been reported in this study that the concentration of $\mathrm{Pb}^{2+}$ in the mine dump waste before employment of mycoremediation scored the highest difference when compared with the LSL for the heavy metal (Fig. 2). This trend in the Nemerow pollution index for the individual heavy metal was, as expected, maintained.

\section{Potential and comprehensive ecological risk assessment for the heavy metals}

The potential (Eqs. 3, 4) and comprehensive (Eqs. 4, 5) ecological risk indices were used in the current study as diagnostic tools for pollution control purposes, and are the basis for attaching special attention for the specific contaminants $\mathrm{Mn}^{2+}, \mathrm{Cr}^{2+}, \mathrm{Pb}^{2+}, \mathrm{Fe}^{3+}$ and $\mathrm{Cd}^{2+}$ within the mine dump sites. 
Table 6 Potential ecological risk indices after bioremediation at Trojan and Freda-Rebecca mine dump sites

\begin{tabular}{|c|c|c|c|c|c|c|c|c|c|c|}
\hline \multirow[t]{2}{*}{ Trt } & \multicolumn{5}{|c|}{ Trojan mine } & \multicolumn{5}{|c|}{ Freda-Rebecca mine } \\
\hline & $\mathrm{Mn}^{2+}$ & $\mathrm{Cr}^{2+}$ & $\mathrm{Pb}^{2+}$ & $\mathrm{Fe}^{3+}$ & $\mathrm{Cd}^{2+}$ & $\mathrm{Mn}^{2+}$ & $\mathrm{Cr}^{2+}$ & $\mathrm{Pb}^{2+}$ & $\mathrm{Fe}^{3+}$ & $\mathrm{Cd}^{2+}$ \\
\hline Trt1 & - & - & - & - & - & - & - & - & - & - \\
\hline Trt2 & $143^{a}$ & $281^{a}$ & $657^{a}$ & $448^{\mathrm{a}}$ & $342^{\mathrm{a}}$ & $141^{\mathrm{a}}$ & $283^{a}$ & $659^{a}$ & $447^{a}$ & $340^{a}$ \\
\hline Trt3 & $110^{b}$ & $149^{b}$ & $310^{b}$ & $136^{b}$ & $141^{b}$ & $113^{b}$ & $147^{b}$ & $313^{b}$ & $137^{b}$ & $139^{b}$ \\
\hline Trt4 & $142^{\mathrm{a}}$ & $279^{a}$ & $655^{\mathrm{a}}$ & $449^{a}$ & $336^{\mathrm{a}}$ & $142^{\mathrm{a}}$ & $277^{a}$ & $659^{a}$ & $451^{\mathrm{a}}$ & $336^{a}$ \\
\hline Trt5 & $100^{c}$ & $110^{c}$ & $123^{c}$ & $113^{c}$ & $111^{c}$ & $102^{c}$ & $111^{c}$ & $122^{c}$ & $114^{c}$ & $113^{c}$ \\
\hline $\operatorname{Lsd}(5 \%)$ & 11 & 23 & 33 & 18 & 42.1 & 12 & 22 & 34 & 16 & 41 \\
\hline Cv\% & 10 & 4 & 5 & 7 & 4 & 5 & 4 & 8 & 8 & 9 \\
\hline
\end{tabular}

Superscripts indicate mean separations that are significant

Table 7 Potential ecological risk indices after bioremediation at Renny and Bindura mine dump sites

\begin{tabular}{|c|c|c|c|c|c|c|c|c|c|c|}
\hline \multirow[t]{2}{*}{ Trt } & \multicolumn{5}{|c|}{ Renny mine } & \multicolumn{5}{|c|}{ Bindura mine } \\
\hline & $\mathrm{Mn}^{2+}$ & $\mathrm{Cr}^{2+}$ & $\mathrm{Pb}^{2+}$ & $\mathrm{Fe}^{3+}$ & $\mathrm{Cd}^{2+}$ & $\mathrm{Mn}^{2+}$ & $\mathrm{Cr}^{2+}$ & $\mathrm{Pb}^{2+}$ & $\mathrm{Fe}^{3+}$ & $\mathrm{Cd}^{2+}$ \\
\hline Trt1 & - & - & - & - & - & - & - & - & - & - \\
\hline Trt2 & $141^{\mathrm{a}}$ & $282^{\mathrm{a}}$ & $658^{\mathrm{a}}$ & $451^{\mathrm{a}}$ & $343^{\mathrm{a}}$ & $143^{\mathrm{a}}$ & $285^{\mathrm{a}}$ & $662^{\mathrm{a}}$ & $449^{a}$ & $344^{\mathrm{a}}$ \\
\hline Trt3 & $112^{\mathrm{b}}$ & $137^{\mathrm{b}}$ & $317^{b}$ & $133^{b}$ & $145^{b}$ & $115^{b}$ & $146^{b}$ & $316^{b}$ & $139^{b}$ & $142^{b}$ \\
\hline Trt4 & $141^{a}$ & $281^{\mathrm{a}}$ & $656^{\mathrm{a}}$ & $453^{\mathrm{a}}$ & $339^{a}$ & $144^{\mathrm{a}}$ & $273^{\mathrm{a}}$ & $663^{\mathrm{a}}$ & $453^{\mathrm{a}}$ & $338^{a}$ \\
\hline Trt5 & $101^{c}$ & $112^{c}$ & $125^{c}$ & $114^{c}$ & $114^{c}$ & $100^{c}$ & $114^{c}$ & $121^{c}$ & $117^{c}$ & $114^{c}$ \\
\hline Lsd (5\%) & 12 & 24 & 34 & 19 & 43 & 13 & 24 & 36 & 18 & 43 \\
\hline CV\% & 4 & 7 & 6 & 6.6 & 9 & 5 & 5 & 8 & 7 & 8 \\
\hline
\end{tabular}

Superscripts indicate mean separations that are significant

Varying the combinations of $P$. ostreatus spawn carrying matter, wheat straw substrate with mine dump waste significantly $(p<0.05)$ influenced the degrees of potential $\left(E_{\mathrm{r}}^{i}\right)$ and comprehensive (RI) ecological harm indices for the selected heavy metals at the four study sites (Tables 3 , $6,7)$. The $E_{\mathrm{r}}^{i}$ and RI values ranged between 46-100 and 170-659, respectively, before treatment with oyster mushroom.

The $E_{\mathrm{r}}^{i}$ and RI ranges clearly indicate that the potential and comprehensive ecological risk levels were light (for $\mathrm{Mn}^{2+}$ ) to very strong (for $\mathrm{Pb}^{2+}$ ) before the employment of bioremediation measures in the experimental mine dump pits (Table 7). The employment of bioremediation measures in the treatment of heavy metals reduced considerably the RI values in the mine dump waste (treatments 3 and 5; Tables 3, 8). The calculated comprehensive potential ecological risk (RI) indices before the bioremediation of the waste showed that the mine dump waste was lightly $\left(\mathrm{Mn}^{2+}\right)$, mildly $\left(\mathrm{Cr}^{2}\right)$, strongly $\left(\mathrm{Fe}^{3+}\right.$ and $\left.\mathrm{Cd}^{2+}\right)$ and very strongly $\left(\mathrm{Pb}^{2+}\right)$ polluted (Tables 7,8$)$. The comprehensive potential ecological risk indices after the bioremediation using $P$. ostreatus in treatment 5 were found in the order of $\mathrm{Mn}^{2+}<\mathrm{Cr}^{2+}<\mathrm{Cd}^{2+}<\mathrm{Fe}^{3+}<\mathrm{Pb}^{2+}$. This implies that the greatest threat to the ecology in the
Mazowe-Pote River catchment areas is currently being posed by $\mathrm{Cd}^{2+}, \mathrm{Fe}^{3+}$ and $\mathrm{Pb}^{2+}$ heavy metals from the mine dump sites. The least ecological threat comes from the concentrations of $\mathrm{Mn}^{2+}$ in the mine dump sites.

The RI values for the mine waste after bioremediation in treatment 5 ranged from 100 to 122 , indicating a safe comprehensive ecological harm index. In plots that had not received mushroom growth, the RI values ranged from 143 for $\mathrm{Mn}^{2+}$ (light ecological risk) to 663 for $\mathrm{Pb}^{2+}$ (very strong ecological risk). The results of the study show that $P$. ostreatus was able to sequestrate the pyritic heavy metals where the combination of wheat straw substrate + dried mushroom + contaminated soil was used as bioremediation material.

\section{Sugar bean seed germination tests on mine dumps after bioremediation}

The fitness of the bio-treated mine dump waste to supply normal conditions for the germination and growth of plants was tested by planting sugar bean seed $(P$. vulgaris L.) in the experimental pits at each mine dump site. Results have shown that germination percentages in replicates pits depended considerably $(p<0.05$; Table 9$)$ on success of colonization and growth of oyster mushroom 
Table 8 Comprehensive potential ecological harm index after the bioremediation

\begin{tabular}{|c|c|c|c|c|c|c|c|c|}
\hline \multirow[t]{2}{*}{ Treatments } & \multicolumn{2}{|c|}{ Trojan mine } & \multicolumn{2}{|c|}{ Freda-Rebecca mine } & \multicolumn{2}{|c|}{ Renny mine } & \multicolumn{2}{|c|}{ Bindura mine } \\
\hline & $E_{\mathrm{r}}^{i}$ & RI & $E_{\mathrm{r}}^{i}$ & RI & $E_{\mathrm{r}}^{i}$ & RI & $E_{\mathrm{r}}^{i}$ & RI \\
\hline Trt1 & - & - & & - & & - & & - \\
\hline Trt2 & $170^{\mathrm{a}}$ & $456^{\mathrm{a}}$ & $172^{\mathrm{a}}$ & $459^{\mathrm{a}}$ & $175^{\mathrm{a}}$ & $460^{\mathrm{a}}$ & $166^{\mathrm{a}}$ & $460^{\mathrm{a}}$ \\
\hline Trt3 & $56^{\mathrm{b}}$ & $211^{\mathrm{b}}$ & $57^{b}$ & $220^{\mathrm{b}}$ & $59^{b}$ & $210^{b}$ & $58^{b}$ & $213^{b}$ \\
\hline Trt4 & $182^{\mathrm{a}}$ & $453^{\mathrm{a}}$ & $182^{\mathrm{a}}$ & $458^{\mathrm{a}}$ & $181^{\mathrm{a}}$ & $457^{\mathrm{a}}$ & $180^{\mathrm{a}}$ & $454^{a}$ \\
\hline Trt5 & $36^{c}$ & $113^{c}$ & $34^{c}$ & $119^{c}$ & $39^{c}$ & $109^{c}$ & $39^{c}$ & $117^{c}$ \\
\hline $\operatorname{Lsd}(5 \%)$ & 10 & 15 & 12 & 9 & 8 & 11 & 12 & 8 \\
\hline Cv\% & 9 & 11 & 11 & 9 & 15 & 7 & 10 & 11 \\
\hline
\end{tabular}

Superscripts indicate mean separations that are significant

Table 9 Seed germination test for bio-treated mine dump waste

\begin{tabular}{|c|c|c|c|c|c|c|c|c|c|c|c|c|}
\hline \multirow[t]{2}{*}{ Trts } & \multicolumn{3}{|c|}{ Trojan mine dump } & \multicolumn{3}{|c|}{ Freda-Rebecca mine dump } & \multicolumn{3}{|c|}{ Renny mine dump } & \multicolumn{3}{|c|}{ Bindura mine dump } \\
\hline & $\begin{array}{l}\text { Planted } \\
\text { seeds }\end{array}$ & Gmd & $\%$ Gmd & $\begin{array}{l}\text { Planted } \\
\text { seeds }\end{array}$ & Gmd & $\%$ Gmd & $\begin{array}{l}\text { Planted } \\
\text { seeds }\end{array}$ & Gmd & $\%$ Gmd & $\begin{array}{l}\text { Planted } \\
\text { seeds }\end{array}$ & Gmd & $\%$ Gmd \\
\hline 1 & 24 & $24^{a}$ & 100 & 24 & $24^{\mathrm{a}}$ & 100 & 24 & $24^{\mathrm{a}}$ & 100 & 24 & $24^{\mathrm{a}}$ & 100 \\
\hline 2 & 24 & $\mathrm{Ob}$ & 0 & 24 & $0^{b}$ & 0 & 24 & $0^{b}$ & 0 & 24 & $0^{\mathrm{b}}$ & 0 \\
\hline 3 & 24 & $5^{c}$ & 21 & 24 & $6^{c}$ & 25 & 24 & $5^{c}$ & 21 & 24 & $4^{c}$ & 17 \\
\hline 4 & 24 & $2^{b}$ & 8 & 24 & $0^{b}$ & 0 & 24 & $2^{b}$ & 13 & 24 & $0^{b}$ & 0 \\
\hline 5 & 24 & $18^{d}$ & 75 & 24 & $20^{d}$ & 83 & 24 & $19^{d}$ & 79 & 24 & $22^{d}$ & 92 \\
\hline Lsd (5\%) & - & 3 & - & - & 2 & - & - & 3 & - & - & 2 & - \\
\hline CV\% & 12 & 9 & 10 & 8 & 7 & 10 & 9 & 5 & 5 & 7 & 4 & 11 \\
\hline
\end{tabular}

Superscripts indicate mean separations that are significant

in the waste. When compared with the control (virgin forest soil), there were small, but significant $(p<0.05$; Table 9) differences in sugar bean seed germination percentages (0-6 germinated seeds) for pits treated with dried shredded mushroom + wheat straw substrate (treatment 5). Seed germination percentages in waste that was successfully colonized by $P$. ostreatus (treatment 5) ranged from 75 to $92 \%$. This clearly implies that the propagation of the oyster mushroom in mine dump waste is capable of detoxifying the environment by reducing the concentrations of heavy metals and increasing the $\mathrm{pH}$ values to be within ranges of safe ecological risks.

\section{Disposal of bioremediation material}

A major challenge for the commercialization of mycoremediation has been the disposal of contaminated mushroom biomass especially in the case of repeated propagation where large amounts of biomass may be produced. The biomass has to be stored, disposed of or utilized in an appropriate manner so as not to pose any environmental risk [25]. Controlled combustion and gasification of biomass can yield a mixture of producer gas and/or pyrogas which can be used to generate thermal and electrical energy. The bio-treated waste can be composted and compacted in order to reduce its volume before reuse. Heavy metals such as Fe and Mn are plant essential metals. The high concentrations of these metals in the harvested biomass can be diluted to acceptable concentrations by combining the biomass with clean biomass in formulations of fertilizer and fodder [2].

\section{Conclusions}

The current study presents an analysis of heavy metal pollution and the possibility for use of a basidiomycetes $P$. ostreatus in the bioremediation of mine dump waste at four selected mine dump sites around the mining town of Bindura in central Zimbabwe. The greatest threat to the ecology in the Mazowe-Pote River catchment areas is currently posed by $\mathrm{Cd}^{2+}, \mathrm{Fe}^{3+}$ and $\mathrm{Pb}^{2+}$ heavy metals from the mine dump sites. The least ecological threat comes from the concentrations of $\mathrm{Mn}^{2+}$ in the mine dump sites. The considerable reduction in the concentrations of heavy metals in the experimental pits that successfully supported vigorous growth of the basidiomycetes clearly implies that the investigated mushroom species is an efficient bio-exlusor of $\mathrm{Mn}^{2+}, \mathrm{Cr}^{2+}, \mathrm{Pb}^{2+}, \mathrm{Fe}^{3+}$ and $\mathrm{Cd}^{2+}$ from their growing environments. The propagation of $P$. ostreatus can be employed as a restoration measure for the soil ecosystems 
contaminated by heavy metals at the mine dump sites. In the biosorption of the heavy metal pollutants, $P$. ostreatus is more efficient in sequestering $\mathrm{Mn}^{2+}, \mathrm{Fe}^{3+}$ and $\mathrm{Cd}^{2+}$, in that order. The biosorption of $\mathrm{Cr}^{2+}$ and $\mathrm{Fe}^{3+}$ from heavy metalpolluted mine waste is less efficient. The propagation of $P$. ostreatus as bioremediation material reduces the individual heavy metal pollution threat in mine dump waste from medium pollution to clean and uncontaminated waste. The use of oyster mushroom propagation in heavy metal decontamination of mine dump waste presents an opportunity to employ renewable green technologies in the remediation of contaminated environments.

\section{Abbreviations}

$17^{\circ} 18^{\prime} \mathrm{S} 31^{\circ} 20^{\prime} \mathrm{E}$ : degrees and minutes east of Greenwich Meridian; GTA: genesis tank atomiser; NIPI: Nemerow integrated pollution index; RI: risk index; ANOVA: analysis of variance.

\section{Authors' contributions}

JM was the main academic supervisor. The field experiment design and layouts were done under his supervision including research write-up, correcting and editing. MM was the main researcher and team member in the field experiments. He participated in all the field work, data collection and analysis; part of the research write-up was done by him. RM was involved in writing the article on the research which was a very difficult business. RM worked tirelessly in field data collection, laboratory sample analyses and guiding this research write-up. KM participated in data analyses especially statistical procedures. He was there right from the beginning up to the end of the field experiments including manuscript write-up. All authors read and approved the final manuscript.

\section{Author details}

1 Department of Land and Water Resources Management, Midlands State University, Private Bag 9055, Gweru, Zimbabwe. ${ }^{2}$ Department of Geography and Environmental Studies, Midlands State University, Private Bag 9055, Gweru, Zimbabwe.

\section{Acknowledgements}

The study constitutes part of the research work carried out in the Faculty of Natural Resources Management and Agriculture of the Midlands State University, Zimbabwe. The researchers acknowledge the University contribution to the research work.

\section{Competing interests}

The authors declare that they have no competing interests.

\section{Availability of data and materials}

The data cannot be shared at this stage because this study is a component of MSc study for a student registered at the Midlands Sate University who is yet to defend the study orally and submit a final thesis for examination.

\section{Consent for publication}

Not applicable.

\section{Ethics approval and consent to participate}

Not applicable. This study did not involve animals.

\section{Funding}

No funding from any funding agency was received for carrying out this research work.

\section{Publisher's Note}

Springer Nature remains neutral with regard to jurisdictional claims in published maps and institutional affiliations.
Received: 17 February 2017 Accepted: 8 August 2017

Published online: 08 October 2017

\section{References}

1. Zimbabwe Chamber of Mines. Zimbabwe Chamber of mines report. In: Zimbabwe Chamber of Mines Editorial Management, Harare, Zimbabwe. 2014. http://www.chamberofminesofzimbabwe.com/slider/mine-entra-2014-2/. Accessed 2 Apr 2017.

2. Cortez H, Pingarrón J, Muñoz J, Ballester A, Blázquez AA, González ML, García F, Coto CO. Bioremediation of soils contaminated with metalliferous mining wastes. In: Plaza G, editor. Trends in bioremediation and phytoremediation. Thiruvananthapuram: Research Signpost Publishers; 2010. p. 230-58.

3. Kumar A, Bish BS, Josh VD, Dhewa T. Review on bioremediation of polluted environment: a management tool. IJES. 2011;1 (6):1079-93.

4. Chibuike GU, Obiora SC. Heavy metal polluted soils: effect on plants and bioremediation methods. Appl Environ Soil Sci. 2014;1:1-12. doi:10.1155/2014/752708.

5. Battaglia-Brunet F, Dictor MC, Garrido F, Crouzet C, Morin D, Dekeyser K. An arsenic (III)-oxidizing bacterial population: selection, characterization, and performance in reactors. J Appl Microbiol. 2002;93:656-67.

6. Gavrilescu M. Removal of heavy metals from the environment by bioremediation. Eng Life Sci. 2004;4:219-32. doi:10.1002/elsc.200420026.

7. Smith VH, Graham DW, Cleland DD. Application of resource-ratio theory to hydrocarbon biodegradation. Environ Sci Technol. 1998;32:3386-95.

8. Strong PJ, Burgess JE. Treatment methods for wine-related and distillery wastewaters: a review. Bioremediation J. 2008;12:70-87.

9. Zimstats. Zimbabwe statistics. 2012th ed. Harare: Government Printers; 2012.

10. Mugandani R, Wuta M, Makarau A, Chipindu B. Re-classification of agroecological regions of Zimbabwe in conformity with climate variability and change. Afr Crop Sci J. 2012;20:361-9.

11. Bartholomew DS. Gold deposits of Zimbabwe. Zimb Geol Surv Miner Resour Ser. 1990;23:73-5.

12. Baldock JW, Styles MT, Kalbskopf S, Muchemwa E. The geology of the Harare Greenstone Belt and surrounding granitic terrain. Zimb Geol Surv Bull. 1991;94:210-3.

13. Darbyshire DPF, Pitfield PEJ, Campbell SDG. Late Archean and early Proterozoic gold-tungsten mineralization in the Zimbabwe Archean craton: $\mathrm{Rb}-\mathrm{Sr}$ and Sm-Nd isotope constraints. Geology. 1996;24:19-22.

14. Jiang X, Lu WX, Zhao HQ, Yang QC, Yang ZP. Potential ecological risk assessment and prediction of soil heavy-metal pollution around coal gangue dump. Nat Hazards Earth Syst Sci. 2014;14:1599-610.

15. Yang ZP, Lu WX, Long YQ, Bao XH, Yang QC. Assessment of heavy metals contamination in urban topsoil from Changchun City, China. J Geochem Explor. 2011:108:27-38.

16. Hakanson L. An ecological risk index for aquatic pollution control: a sedimentological approach. Water Res. 1980;14:975-1001. doi:10.1016/0043-1354(80)90143-8.

17. Douay F, Pelfrene A, Planque J, Fourrier H, Richard A, Roussel H, Girondelot B. Assessment of potential health risk for inhabitants living near a former lead smelter, Part 1: metal concentrations in soils, agricultural crops, and home-grown vegetables. Environ Monit Assess. 2013;185:3665-80. doi:10.1007/s10661-012-2818-3.

18. VSN International. GenStat discovery GenStat for windows. 7th ed. Oxford: VSN International; 2003.

19. Demirbas A. Concentrations of 21 metals in 18 species of mushrooms growing in the East Black Sea region. Food Chem. 2001;75:453-7.

20. Campos JA, Tejera NA. Substrate role in the accumulation of heavy metals in sporocarps of wild fungi. Biometals. 2009;22:835-41.

21. Gutierrez A, Martinez AT, Prieto A. Structural characterization of extracellular polysaccharides produced by fungi from the genus Pleurotus. Carbohydr Res. 1996;281:143-54.

22. Das N. Heavy metals biosorption by mushrooms. NPR. 2005:4:454-9.

23. Stihi C, Radulescu C, Busuioc G, Popescui IV, Gheboianu A, Ene A. Studies on accumulation of heavy metals from substrate to edible wild mushrooms. Rom Journ Phys. 2009;56(1-2):257-64. 
24. Siric I, Kos I, Bedekovic D, Kaic A, Kasap A. Heavy metals in edible mushrooms Boletus reticulatus Schaeff collected from Zrin mountain, Croatia. Period Biol. 2014;116(3):319-22.

25. Khaled SB, Muhammad AA. Field accumulation risks of heavy metals in soil and vegetable irrigated with sewage water in western region of Saudi Arabia. Saudi J Biol Sci. 2016;23:32-44.

26. Kojta KA, Zhang D. Survey on composition and bioconcentration potential of 12 metallic elements in King Bolete (Boletus edulis) mushroom that emerged at 11 spatially distant sites. J Environ Sci. 2011;46:231-46.

27. Lamrood PY, Ralegankar SD. Biosorption of Cu, Zn, Fe, Cd, Pb and Ni by non-treated biomass of some edible mushrooms. Asian J Exp Biol Sci. 2013;4:190-5.
28. Shweta K, Nupur M, Prdeep B. Mushroom as a product and their role in mycoremediation. AMB Express. 2014;4:1-29.

29. Fei L, Jing-po Y, Han L. Risk evaluation of heavy metals in soil in the sewage irrigation area: a case study of Shijiazhuang. J Chem Pharm Res. 2014;6(6):2147-52.

30. Aydinalp C, Marinova S. Distribution and forms of heavy metals in some agricultural soils. Pol J Environ Stud. 2003;12(5):629-33.

\section{Submit your manuscript to a SpringerOpen ${ }^{\odot}$ journal and benefit from:}

- Convenient online submission

- Rigorous peer review

- Open access: articles freely available online

- High visibility within the field

- Retaining the copyright to your article

Submit your next manuscript at $\mathbf{s p r i n g e r o p e n . c o m ~}$ 